\title{
NDRG4 When you get on the gut's nerves
}

Citation for published version (APA):

Vaes, N. (2019). NDRG4 When you get on the gut's nerves. [Doctoral Thesis, Maastricht University]. Gildeprint Drukkerijen. https://doi.org/10.26481/dis.20190927nv

Document status and date:

Published: 01/01/2019

DOI:

10.26481/dis.20190927nv

Document Version:

Publisher's PDF, also known as Version of record

\section{Please check the document version of this publication:}

- A submitted manuscript is the version of the article upon submission and before peer-review. There can be important differences between the submitted version and the official published version of record.

People interested in the research are advised to contact the author for the final version of the publication, or visit the DOI to the publisher's website.

- The final author version and the galley proof are versions of the publication after peer review.

- The final published version features the final layout of the paper including the volume, issue and page numbers.

Link to publication

\footnotetext{
General rights rights.

- You may freely distribute the URL identifying the publication in the public portal. please follow below link for the End User Agreement:

www.umlib.nl/taverne-license

Take down policy

If you believe that this document breaches copyright please contact us at:

repository@maastrichtuniversity.nl

providing details and we will investigate your claim.
}

Copyright and moral rights for the publications made accessible in the public portal are retained by the authors and/or other copyright owners and it is a condition of accessing publications that users recognise and abide by the legal requirements associated with these

- Users may download and print one copy of any publication from the public portal for the purpose of private study or research.

- You may not further distribute the material or use it for any profit-making activity or commercial gain

If the publication is distributed under the terms of Article $25 \mathrm{fa}$ of the Dutch Copyright Act, indicated by the "Taverne" license above, 
ETCETERA

SAMENVATIING 

Wereldwijd is dikke darmkanker nog steeds een van de meest voorkomende vormen van kanker waarbij ongeveer de helft van alle dikke darmkankerpatiënten sterft aan hun ziekte. Zoals besproken in HOOFDSTUK 1 wordt dit voornamelijk toegeschreven aan het feit dat dikke darmkanker nog steeds niet geheel succesvol te behandelen is. De reden hiervoor is dat deze tumoren zeer complex en heterogeen zijn, en ook sterk beïnvloed worden door de tumor micro-omgeving. Dit alles maakt dat de doeltreffendheid van behandelingen en overlevingskansen sterk kunnen variëren, zelfs tussen patiënten met tumoren in eenzelfde stadium. Echter, wanneer dikke darmkanker in een vroeg stadium wordt gedetecteerd, stijgen de 5-jaar overlevingskansen aanzienlijk, tot ongeveer $90 \%$. Momenteel is de vroege detectie van dikke darmkanker nog steeds zeer moeilijk door de afwezigheid van klinische symptomen in de initiële ziektefasen. Dankzij de nationale bevolkingsonderzoeken naar dikke darmkanker, die o.a. gebruik maken van een test die bloed opspoort in de ontlasting (de 'fecal immunochemical test' (FIT)), worden vandaag de dag meer dikke darmkankers gedetecteerd alvorens deze zijn uitgezaaid/in een verder gevorderd stadium zitten en dus minder goed behandelbaar zijn. Niettemin is de FIT niet optimaal aangezien bloed in de ontlasting niet altijd duidt op de aanwezigheid van dikke darmkanker. Daarom zijn het onderzoek en de ontwikkeling van meer specifieke en niet-invasieve technieken die (dikke) darmkanker kunnen aantonen in lichaamsvloeistoffen, zoals biomarkers (voornamelijk DNA methylatie), sterk in opmars.

Ondanks de beperkte klinische translatie van de meest ontdekte biomarkers $(<1.0 \%)$, werd de DNA methylatie biomarker ontdekt door Melotte et al: N-Myc Downstream-regulated Gene 4 (NDRG4) succesvol geïncorporeerd in de Cologuard ${ }^{\circledR}$, een FDA-goedgekeurde multi-target ontlastings-DNA test, die in Amerika gebruikt wordt voor de vroege detectie van CRC. Gezien de uiterst beperkte kennis over de expressie en functies van NDRG4 in het maagdarmkanaal, was het belangrijkste DOEL van dit proefschrift om de functie van NDRG4 in de ontwikkeling en functioneren van het maagdarmkanaal en gedurende dikke darmkanker te onderzoeken.

Voordat we de functies in het maagdarmkanaal konden ophelderen, moesten we eerst bepalen in welke cellen NDRG4 zich bevindt in het lichaam en voornamelijk binnen het maagdarmkanaal (HOOFDSTUK 2). Nadat we een selectief én specifiek antilichaam tegen NDRG4 hadden gevonden (Cell Signaling, \#9039), observeerden we de specifieke aanwezigheid van NDRG4 in neuronen (zenuwcellen) van het centraal en perifeer zenuwstelsel, zoals voorheen beschreven. Verrassend, maar in overeenkomst met twee publicaties die verlaagde NDRG4 niveaus beschreven in de aganglionaire darm, ontdekten we de specifieke aanwezigheid van NDRG4 in zenuwcellen en zenuwvezels van het intrinsieke zenuwstelsel van het maagdarmkanaal: 'het enterisch zenuwstelsel' (ENS), bij zowel muizen als mensen. Hoewel we de accurate biomarker prestaties van NDRG4 
in dikke darmkanker nog niet kunnen linken met zijn ENS-specifieke expressie, leidde deze ontdekking wel tot de vraag of het ENS mogelijk kan bijdragen aan de ontwikkeling/ progressie van dikke darmkanker.

Deze vraag werd verder behandeld in HOOFDSTUK 3, waarin we eerst het belang van het ENS in het maagdarmkanaal hebben samengevat. Het maagdarmkanaal is het enige orgaan in de periferie dat "een eigen brein" heeft, namelijk het ENS. Dit is een functioneel neuroglial circuit dat onmisbaar is voor het succesvol functionerenvan het maagdarmkanaal. Neuronen en glial cellen werken nauw samen en zullen afhankelijk van de luminale stimulus geschikte signalen, in de vorm van boodschappermoleculen (verpakt in een membraneus blaasje), verzenden naar de gewenste darmcel(len). Elk neuron, exciterend (acetylcholine; Ach) of inhiberend (nitric oxide; NO), produceert verschillende secundaire boodschappers zoals serotonine (5-HT), Substance P, vasointestinal active polypeptide (VIP), calcitonin generelated peptide (CGRP) en NPY, die de cellulaire prestaties van hun primaire effectorcellen bepalen. Opmerkelijk, gezien het belang van het ENS in de homeostase van de darm en de eerste aanwijzing over zijn betrokkenheid in darmkanker in 1996, werd het onderzoek naar dit onderwerp niet voortgezet, zelfs ondanks toenemend bewijs dat (zenuw-) cellen/ signalen in de tumor micro-omgeving bijdragen aan (dikke) darm carcinogenese. Niettemin hebben we, na de opheldering dat boodschappermoleculen zoals 'nerve-growth factor' (NGF) darmcelgroei en (dikke) darmkanker kunnen beïnvloeden, de hypothese naar voren gebracht dat het ENS een invloed kan hebben op (dikke) darmkanker vanwege zijn (in-) directe communicatie met het darmepitheel.

Vervolgens gingen we in HOOFDSTUK 4, 5 en 6 verder opzoek naar de functies die NDRG4 vervult in de ontwikkeling van de darm maar ook gedurende darmkanker.

In HOOFDSTUK 4 combineerden we hiervoor literatuur en in silico data en toonden aan dat, ondanks hun verschillende expressie patroon, elk NDRG familielid - behalve NDRG3 - beschreven wordt als een diagnostische (NDRG4), prognostische (NDRG1, 2 en 4) en predictieve (NDRG1) biomarker voor CRC. Daarnaast beschreven we ook dat de NDRG familieleden betrokken zijn bij het transport van blaasjes aangezien (i) NDRG4 gelinkt werd aan VAMP-3 positieve blaasjes en SNAP-25, (ii) NDRG1, 2 en 3 interageren met een eiwit betrokken in exocytose: PRA1 en (iii) NDRG3 samenwerkt met CPLX1 om synaptische exocytose te reguleren. Bovendien hebben NDRG1, 2 en 4 tumor onderdrukkende functies in dikke darmkanker, voornamelijk door het remmen van proliferatie en de epitheliale naar mesenchymale transitie (EMT). 
Daar de hierboven beschreven effecten alleen aangetoond werden in (tumor) epitheel cellen, probeerden we de rol van enterisch neuronaal NDRG4 in darmkanker te bepalen in HOOFDSTUK 5. Door gebruik te maken van twee alom-bekende muismodellen voor CRC (APC ${ }^{\mathrm{min} /+}$ en azoxymethane behandelingsmodel) vonden we dat NDRG4 een invloed heeft op de pathogenese van (dikke) darmkanker. Darmpoliepen die groeiden in afwezigheid van NDRG4 waren gekenmerkt door een vergrootte diameter en een verhoogde kerncontent van $\beta$-catenine. Ook zagen we, in overeenkomst met een voorgaande studie, dat knockdown van NDRG4 geassocieerd is met de verstoring van het intracellulaire transport van blaasjes. Aan de hand van een indirect co-culture model van primaire ENS cellen en 3D darmepitheelorganoïden vonden we dat knockdown van NDRG4, via de veranderde uitscheiding van boodschappermoleculen, de groeisnelheid van darmcellen verhoogt. Samen tonen deze data het potentieel van NDRG4/ENS als een belangrijke factor in de omgeving van de tumor en benadrukken ze de noodzaak om de rol van het ENS in CRC verder te onderzoeken.

Tot slot onderzochten we in HOOFDSTUK 6 of NDRG4 de ontwikkeling van het ENS en darmmotiliteit beïnvloedt aan de hand van een zebravis model (Danio Rerio) dat het fluorescente kaede-eiwit in enterische neuronen tot expressie brengt. We zagen dat knockdown van ndrg4 geassocieerd was met een significante vermindering van het aantal enterische neuronen in de distale darm, hetgeen mogelijks kan toegeschreven worden aan een defecte $\beta 1$-integrin clustering ter hoogte van het celoppervlak of een verstoorde afzetting van extracellulaire matrixmoleculen. Vervolgens observeerden we dat peristaltische golven over een kortere afstand voortbewogen in afwezigheid van ndrg4, hetgeen hoogstwaarschijnlijk veroorzaakt wordt door ontoereikende signalering naar spiercellen. Er is echter verder onderzoek nodig om te bestuderen of deze mechanismen effectief aan de basis liggen van deze veranderingen.

Het belang van de bevindingen beschreven in dit proefschrift werden samengevat en bediscussieerd in HOOFDSTUK 7. Dit proefschrift onthulde dat NDRG4, één van de meest accurate vroege detectie markers voor dikke darmkanker, specifiek tot expressie komt in het ENS en toonde aan dat NDRG4 en het ENS mogelijk een belangrijke rol hebben in de ontwikkeling van (dikke) darmkanker. Bovendien wijst het erop dat NDRG4 een rol speelt in de ontwikkeling van het ENS en darmmotiliteit. Na het kritisch bespreken van de tekortkomingen van enkele van onze experimentele opstellingen, stellen we verbeterde studieontwerpen voor om de hier-beschreven bevindingen te valideren en verder uit te diepen. Al met al voedt dit proefschrift de discussie over de bijdrage van het ENS aan (dikke) damkanker en de mogelijkheid om zenuwcel (-afgeleide) targets te vinden voor succesvolle screening of voor de ontwikkeling van patiënt-specifieke behandelingen. 